\title{
Model of Green Building: The Malaysia Energy Commission Diamond Building
}

\author{
Qiwei Fan \\ Faculty of Architecture and Built Environment, Infrastructure University Kuala Lumpur, Kajang, Malaysia \\ Email:645961770@qq.com
}

How to cite this paper: Fan, Q.W. (2020) Model of Green Building: The Malaysia Energy Commission Diamond Building. Open Access Library Journal, 7: e6940. https://doi.org/10.4236/oalib.1106940

Received: October 28, 2020

Accepted: November 27, 2020

Published: November 30, 2020

Copyright $\odot 2020$ by author(s) and Open Access Library Inc.

This work is licensed under the Creative Commons Attribution International License (CC BY 4.0).

http://creativecommons.org/licenses/by/4.0/ (c) (i) Open Access

\begin{abstract}
Green building is a very popular building type in the current building market. Green building is energy-saving, low-carbon, environmental-friendly builds. Most buildings in today's society are influenced by green buildings. There are many ways to achieve green building. The Malaysia Energy Commission Diamond Building is a model of green building design. The purpose of this paper is to study architectural design of the building and learn how the designer skillfully combines green building with modern architecture. The study was carried out by visiting the building and collecting information about the building. Investigations revealed the building uses novel building structures and cooling systems. The architects used low-carbon materials to save a lot of energy for the building. The green landscape surrounding the building provides a cool and comfortable working environment for the staff. Finally, the Malaysia Energy Commission Diamond Building provides a useful reference for the sustainable design of modern buildings.
\end{abstract}

\section{Subject Areas \\ Green Building \\ Keywords \\ Green Building, Energy Conservation, Water Conservation, Indoor \\ Environmental Quality, Outdoor Environmental Quality}

\section{Introduction}

The Malaysia Energy Commission Diamond Building is located at Precinct 2, Putrajaya, Adjacent to Taman Pancarona, it is an example of green building design (Figure 1). The building has seven floors above ground and two underground floors for parking. The gross floor area (GFA) of the building is $14,230 \mathrm{~m}^{2}$, 




Figure 1. The diamond building.

and its green landscape area is $3600 \mathrm{~m}^{2}$ [1]. Due to the high cost of energy and its environmental impact, energy consumption in buildings needs to be reduced both at the building conceptual design stage and the building in use [2]. It has been ascertained that the applications of innovative energy efficient design of buildings have the advantage of reducing total energy consumption of a building [3]. The building adds to the comfort of interior office environment by reflecting sunlight and noise through a special diamond-shaped overall structure. At the same time, it could use the thin film telluride module type photovoltaic (PV) panels to harvest sunlight and convert it into energy, generating about $10 \%$ of the building's energy needs from the approach. The surrounding landscape of the building is also designed as a green landscape. The building collects rainwater through stormwater pipes, which is used to irrigate the garden. The green landscape provides a cool environment for the building's occupants. Many details of internal structure of the building are cleverly designed to provide a comfortable working environment for staff inside the building. At the same time, the interior of building is very spacious, and the staff has a large space for activities. The architects used a lot of low carbon materials, such as plasterboard and paint with low VOC (Volatile Organic Compounds) content. The Malaysia Energy Commission Diamond Building was designed and manufactured based on the concept of sustainable building. The environmental protection concept of the building design is mainly reflected on four aspects: energy conservation, water conservation, indoor environmental quality and outdoor environmental quality. The purpose of this paper is to study the architectural design of this building and to understand how the designer can combine green building with modern building skillfully. By analyzing the design advantages of building to prove that green environmental protection can be combined with the aesthetics of building and low operating costs. The study was carried out by visiting the building and collecting information about the building.

\section{Energy Conservation}

The exterior of The Malaysia Energy Commission Diamond Building was chosen for its philosophical and practical value, resulting in an iconic office building. Diamonds symbolize transparency, value and durability. The unique shape 
of diamonds was chosen after long-term thinking and study of the surrounding environment of the building. In tropical climate countries such as Malaysia, self-shading system is suggested to be a potential solution to prevent solar radiation [4]. Solar studies show that $25^{\circ}$ tilting facades would provide self-shading on the north and south facades [5]. The building's slopping facade protects the building from direct sunlight, thus reducing the footprint of the building and creating a larger landscape area. The diamond-shaped exterior of the building maximizes the use of light and introduces it to the building's atrium. The centerpiece of the building is a large central atrium designed to admit and regulate daylighting using "an automatic roller-blind system responsive to the intensity as well as the angle of the incident sunlight" according to the Energy Commission [6]. The diamond-shaped form of the building adds ground space that can be used for landscaping, which helps reduce the heat island effect. The facade of the building is made of low-E glass, which has a visual transmittance (VLT) of more than 0.5 , effectively providing natural lighting to the interior of the office. All the exterior façade have split window design with internal light shelves to increase the illuminance level of natural light deeper into the office working space [7]. Low-E glass also helps to reduce direct solar heat absorption on the surface of the building.

Materials used in the Malaysia Energy Commission Diamond Building can also reduce the massive energy consumption of building. Diamond-shaped skylights in the building's atrium are laminated tempered glass, designed to provide uniform and non-glare daylight to offices around the atrium. In order to reduce the heat absorption of the building, the top of the roof is also insulated with panels. The building is also installing the thin film telluride module type photovoltaic (PV) panels in the roof and reducing the building's energy use by $10 \%$. A majority of the building energy consumptions are from thermal and lighting loads [8]. Energy-saving lighting is used throughout the building, and integration with daylight sensors can save energy by turning off artificial lighting when there is plenty of daylight. The office area inside the building uses a large number of energy-saving office equipment. The Diamond Building is designed with a BEI (Building Energy Index) of $85 \mathrm{kWh} / \mathrm{m}^{2}$ per year at 2800 hours usage, a $65 \%$ reduction in energy consumption. The building's average BEI is at $65 \mathrm{kWh} / \mathrm{m}^{2}$ per year [5].

\section{Water Conservation}

The methods used by the architects in water efficiency of the Malaysia Energy Commission Diamond Building include: collection and reuse of rainwater, efficient water fittings and greywater recycling for wetland. The building uses its own energy to collect rainwater, most of which is collected from rainwater sewers on the roof and drains around the building. Rainwater slides from the roof in four directions to stormwater pipes, from which it flows into tanks (Figure 2). The tank capacity is approximately 2400 gals. The collected rainwater is mainly 


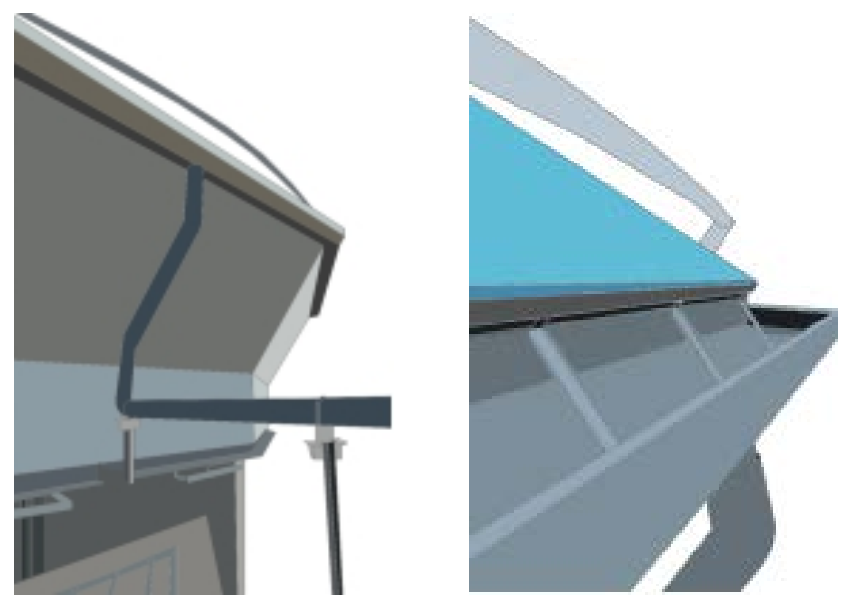

Figure 2. Roof drainage pipe for rainwater.

used for flushing toilets and irrigation. Using this method, the building can save about $35.2 \%$ of water. The building saves $818 \mathrm{~m}^{3}$ of water per year. Water-saving accessories such as dual-flush toilets and anhydrous urinals are used inside the building, which uses $67 \%$ less water than other accessories. In order to optimize the efficiency of the building, the sewage collected from the washbasins is also recycled: irrigating the wetlands. These waste water will not be stored for more than 24 hours and the excess waste water will be discharged into the town sewage system. These designs can save a lot of water consumption of the building every year. The design of water conservation in this building provides a good example for the sustainable development of green buildings.

\section{Indoor Environmental Quality}

The interior of The Malaysia Energy Commission Diamond Building is illuminated with an energy-efficient system. The energy-efficient artificial lighting system is daylight responsive. The lighting load is $2.5 \mathrm{Btu} / \mathrm{ft}^{2}\left(8 \mathrm{~W} / \mathrm{m}^{2}\right)$ with an illumination level of $27.9 \mathrm{fc}$ (300 lux) to $37.16 \mathrm{fc}$ (400 lux), conforming to Malaysian Standard 1525-2007 [9]. The interior of the building uses T5 fluorescent tubes instead of the traditional T8 fluorescent tubes. The luminance, life and stability of T5 fluorescent tubes are far beyond those of T8 fluorescent tubes. In terms of energy saving, the ratio of 28 to $36+9$ is obvious, and T5 fluorescent tube can help the building to save energy. The building's internal energy-efficient lighting system integrates with daylight sensors to save energy by turning off artificial lighting when there is plenty of daylight. The building is also equipped with an energy-saving cooling system to match the local hot climate in Malaysia. The cooling system inside The Malaysia Energy Commission Diamond Building was provided by radiating cooling plates embedded with chilled water pipes (Figure 3). This design greatly reduces the air flow rate inside the pipes and reduces noise inside the building. The staff inside building can feel quiet and comfortable. Compared to traditional architecture, the building uses fewer materials: suspended ceilings have been removed from most of the interior spaces. 


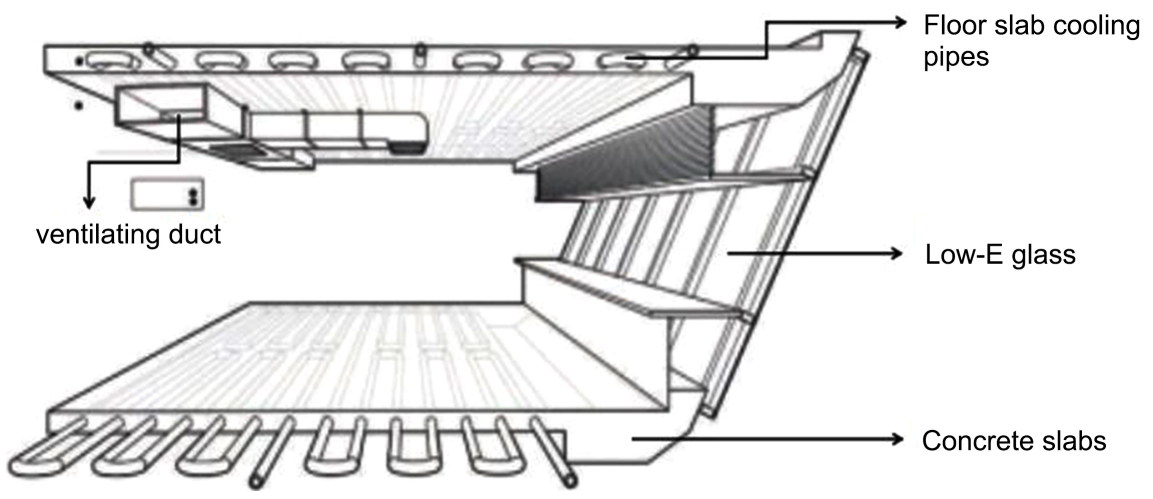

Figure 3. The building's internal cooling system (Source: Greening Asia, Emerging Principles for Sustainable Architecture).

The building uses low carbon and energy efficient materials to decorate the interior spaces, such as energy efficient plasterboard and energy efficient flooring, which can be recycled. Gypsum board has a low VOC emission and its recoverable content is $30 \%$. The floors inside the building are at least $10 \%$ recyclable. The interior of building is also painted with low VOC content. The use of energy-saving and low-carbon materials in this building not only saves costs, but also does not cause pollution to the surrounding environment. These materials can absorb heat and sunlight, bringing a cool working environment for indoor workers. The interior of the building is also designed to facilitate energy recovery and sustainability.

\section{Outdoor Environmental Quality}

The exterior of The Malaysia Energy Commission Diamond Building is surrounded by greenery. The designers have placed extensive landscaping and outdoor gardens on the exterior of building. Buildings that are close to or surrounded by green plants have lower ambient temperatures than buildings that are far away from green plants. This design not only ensures the green space, but also provides a cool and beautiful environment for the office staff and occupants inside the building. Looking at the green landscape during breaks helps to protect the eyesight and relax the staff. The large amount of green plants can not only create a beautiful landscape but also absorb a lot of carbon dioxide to reduce the temperature around building. Workers at the building used saved sewage and rainwater to irrigate the plants, which saved a lot of water. The garden was also fertilized with landscape garbage and food waste. This reduces the cost of fertilizer and recycles resources instead of making waste. The green roof of the building can further reduce the heat and impact of city, and such design increases the green landscape of city. The building is also surrounded by a large number of parking lots for green car and bike, which are designed to encourage the building's interior staff and occupants to use green cars or bikes to get to work. Such a design would reduce carbon dioxide emissions from the building and the surrounding area. Reduced carbon dioxide emissions of 1400 tonnes per 
year, akin to taking 700 cars off the road. (Assuming each car has travelled 12,000 km.) [10]. The designers of The Malaysia Energy Commission Diamond Building have made a significant contribution to the conservation of natural environment by increasing the number of green car parking lots and promoting green travel.

\section{Conclusion}

The Malaysia Energy Commission Diamond Building is a physical demonstration landmark; it is an example of green modern building design. Its success illustrates the financial viability of green building. The building also makes a significant contribution to sustainable development and energy conservation in Malaysia. The building proves that being green is not expensive, and that the aesthetic design of building does not contradict the sustainable development of green buildings. The architects used slopping glass walls to reflect sunlight so that the light inside building would not be too harsh. The glass walls absorb a lot of heat and maintain the temperature inside room. The architects used solar panels on the roof to convert sunlight into energy for the building, this design could save the building a lot of energy. The architects also used drains of roof to collect rainwater and optimized the building's water efficiency by purchasing water-saving accessories, which resulted in the building saving about $35.2 \%$ of water. The architects used a large number of energy-efficient materials in designing the building's overall structure. The building's internal cooling and lighting systems reduce the internal consumption of building while providing a comfortable working environment for the staff. These designs are for the sustainable development of the building and save a lot of operating costs. The Malaysia Energy Commission Diamond Building proves that green building can be combined with beautiful and low operating costs.

\section{Acknowledgements}

I would like to thank the relevant staff for providing a lot of materials in the writing process of this paper.

\section{Conflicts of Interest}

The author declares no conflicts of interest regarding the publication of this paper.

\section{References}

[1] IGEM 2012 MGBC (2012) Diamond Building. http://www.mgbc.org.my/Downloads/IGEM2012/IGEM2012\%20-\%20MGBC\%20S T\%20Diamond\%20Building.pdf

[2] Kandar, M.Z., Nimlyat, P.S., Abdullahi, M.G. and Dodo, Y.A. (2016) A Field Study of Thermal and Visual Performance of Self-Shading Energy Commission Diamond Building, Putrajaya, Malaysia. Indian Journal of Science and Technology, 9, 1-16. https://doi.org/10.17485/ijst/2016/v9i46/107120 
[3] Cambiaso, F. (2013) Architectural Integration of Dynamic and Innovative Technologies for Energy Saving. CISBA T2013: Cleantech for Smart Cities and Buildings from Nano to Urban Scale. Lausanne, EPFL, Switzerland, 79-84.

[4] Asia Green Buildings (2013) Malaysia’s Diamond Building, Designing Shading System in a Tropical Climate.

http://www.asiagreenbuildings.com/7763/malaysias-diamond-building-designing-s hading-system-tropical-climate/

[5] Energy Commission (n.d.) The Energy Commission Diamond Building. https://www.st.gov.my/en/details/aboutus/9

[6] Al Bredenberg (2012) Malaysia’s Stunning Green Diamond Building Wins Southeast Asia Energy Prize.

https://inhabitat.com/malaysias-green-diamond-building-wins-southeast-asia-ener gy-prize/

[7] Kandar, M.Z., Nimlyat, P.S., Abdullahi, M.G. and Dodo, Y.A. (2019) Influence of Inclined Wall Self-Shading Strategy on Office Building Heat Gain and Energy Performance in Hot Humid Climate of Malaysia. Heliyon, 5, e02077.

https://doi.org/10.1016/j.heliyon.2019.e02077

[8] Xin, H.Z. and Rao, S.P. (2013) Active Energy Conserving Strategies of the Malaysia Energy Commission Diamond Building. Procedia Environmental Sciences, 17, 775-784. https://doi.org/10.1016/j.proenv.2013.02.095

[9] TL Chen, P.E., C.Eng., Fellow ASHRAE and Ahmad Izdihar, P.E (2014) Malaysia Energy Commission Headquarters: Putrajaya, Malaysia. High Performing Buildings, Fall 2013, 20-33.

https://www.hpbmagazine.org/malaysia-energy-commission-headquarters-putrajay a-malaysia

[10] Koay, A. (2011) Diamond Building: A Shining Example of Energy Efficiency. https://www.thestar.com.my/lifestyle/features/2011/07/05/diamond-building-a-shin ing-example-of-energy-efficiency 